\title{
Development and characterization of polymorphic microsatellite markers for Chinese raccoon dog (Nyctereutes procyonoides procyonoides)
}

\author{
S.Q. Yan ${ }^{1 *}$, Y.M. Li ${ }^{1 *}$, C.Y. Bai ${ }^{1}$, X.M. Ding ${ }^{1}$, W.J. Li ${ }^{1}$, J.N. Hou ${ }^{1}$, \\ Z.H. Zhao ${ }^{1}$ and J.H. Sun ${ }^{1,2}$ \\ ${ }^{1}$ College of Animal Science, Jilin University, Changchun, China \\ ${ }^{2}$ College of Animal Science and Veterinary Medicine, \\ Qingdao Agricultural University, Qingdao, China \\ *These authors contributed equally to this study. \\ Corresponding author: J.H. Sun \\ E-mail: jhsun0528@163.com
}

Genet. Mol. Res. 12 (4): 6351-6355 (2013)

Received March 22, 2013

Accepted August 29, 2013

Published December 6, 2013

DOI http://dx.doi.org/10.4238/2013.December.6.2

\begin{abstract}
Chinese raccoon dog (Nyctereutes procyonoides procyonoides) is one of the most important fur-bearing animal species. Information about the genetic background of farmed Chinese raccoon dogs is limited. In this study, 17 polymorphic microsatellite markers were isolated and identified from an (AC) $)_{\mathrm{n}}$-microsatelliteenriched library of Chinese raccoon dogs. The number of alleles per locus ranged from 2 to 8 based on 48 individuals tested. The expected and observed heterozygosity and polymorphism information content per locus ranged from 0.383 to $0.8378,0.3200$ to 0.8696 , and 0.3047 to 0.7947 , respectively. Cross-species amplification of these loci in 2 other Canidae species indicated that 9 and 11 of these loci could also be amplified successfully in the arctic and silver fox, respectively. These microsatellite loci developed in the present report will provide
\end{abstract}


useful tools for population genetic studies, individual identification, and phylogenetic analysis in the Chinese raccoon dog and other Canidae species.

Key words: Microsatellite markers; Nyctereutes procyonoides procyonoides; Cross-amplification

\section{INTRODUCTION}

The Chinese raccoon dog (Nyctereutes procyonoides procyonoides), belonging to the Canidae family, is an important fur animal that is raised for its fur in the clothing industry. During the past 20 years, unfavorable inbreeding depression has led to degeneration in this species, especially for some economically important traits, such as fur quality, litter size, and body size. Therefore, measures should be adopted to avoid the breed deterioration and to develop new varieties. Microsatellites are sequences consisting of simple sequence repeats (SSR) (Zhao and Kochert, 1993), which have been proven to be powerful tools to assess population genetic parameters because of their high degree of polymorphism, codominant inheritance, and abundance in the eukaryotic genome (Sha et al., 2009; Ma and Chen, 2011). Nevertheless, microsatellite loci for Chinese raccoon dog are very limited in number and were developed mainly based on cross-species amplifications using canine SSR primer pairs (Hayashizono et al., 2010; Slaska et al., 2010). The aims of this study are to isolate and characterize new microsatellite markers with polymorphism for Chinese raccoon dog from a microsatellite-enriched library.

\section{MATERIAL AND METHODS}

\section{$(\mathrm{AC})_{\mathrm{n}}$-enriched library construction}

Genomic DNA was extracted from muscle tissues of 48 unrelated fur-bearing Chinese raccoon dogs, 4 arctic foxes, and 4 silver foxes using UNIQ-10 Column Genomic DNA Isolation Kit (Sangon, Shanghai, China). Animal experiments were done in accordance with the guidelines on animal care and use established by the Jilin University Animal Care and Use Committee. The genomic (AC) -enriched library was constructed according to Novelli et al. (2006) with modifications. Briefly, genomic DNA from 1 male individual was completely digested with the Sau3AI restriction enzyme (TaKaRa, Dalian, China). After agarose gel electrophoresis, fragments arranging from 200 to $1000 \mathrm{bp}$ in size were recovered and ligated with Sau3AI adapters (Linker 1: 5'-PO-GATCGCAGAATTCGCACGAGTACTAC-3'; Linker 2: 5'-GTAGTACTCGTGCGAATTCTGC-3'). Fragments containing (GT/CA) microsatellite sequences were enriched by hybridizing to $(\mathrm{AC})_{13}$ biotin-labeled probe and separated with streptavidin magnetic beads (Promega, USA), according to manufacturer instructions. DNA fragments were eluted and amplified by polymerase chain reaction (PCR) using Linker 2 as the primer. PCR products were ligated into the pMD18-T vector (TaKaRa) and transformed into Escherichia coli DH5 a competent cells. The clones containing microsatellite DNA inserts were identified, following the procedure described by Lunt et al. (1999), and sequenced. Each colony was named with the prefix NPPM ( $N$. procyonoides procyonoides Microsatellite) followed by a number. 


\section{PCR and genotyping of microsatellite loci}

Primer pairs were designed for clones containing more than 8 repeats using the Primer Premier 6.10 software (http://www.premierbiosoft.com/) according to the flanking sequences of the repetitive region. For each primer pair, the forward primer included an M13 (-21) tail (5'-TGTAAAACGACGGCCAGT-3') at its 5' end. To optimize the PCR conditions, preliminary analyses were conducted with a sample set of 4 individuals. Loci with specific amplification patterns were further genotyped in 48 unrelated individuals according to the method described by Schuelke (2000) with modifications. The PCR was conducted in a $25-\mu \mathrm{L}$ reaction system containing approximately $10 \mathrm{ng}$ genomic DNA, $1 \mathrm{X}$ Taq polymerase buffer with $\mathrm{Mg}^{2+}, 0.1 \mathrm{mM}$ of each dNTP, $0.5 \mathrm{U}$ Taq polymerase (TaKaRa), $0.025 \mu \mathrm{M}$ M13 (-21)-tailed forward primer, $0.1 \mu \mathrm{M}$ M13 (-21)-tagged primer labeled with fluorescence (either FAM, HEX, or TAMARD), and $0.1 \mathrm{mM}$ reverse primer. Amplification was conducted on a GeneAmp PCR System 9700 (Applied Biosystems, USA) under the following conditions: initial denaturing at $95^{\circ} \mathrm{C}$ for $3 \mathrm{~min} ; 30$ cycles of $94^{\circ} \mathrm{C}$ for $30 \mathrm{~s}, 58^{\circ} \mathrm{C}$ for $30 \mathrm{~s}$, and $72^{\circ} \mathrm{C}$ for 30 $\mathrm{s}$; and $72^{\circ} \mathrm{C}$ for $20 \mathrm{~min}$. The amplified products were separated and visualized on $1.5 \%$ agarose gel with ethidium bromide. The products that showed clear and scorable amplification patterns were separated on an ABI 3730 DNA sequencer (Applied Biosystems). The sizes of alleles were estimated using the Genemapper 4.0 software and the GeneScan-500 internal size standard (Applied Biosystems).

\section{Polymorphic information evaluation}

The polymorphic information of each locus was assessed using the CERVUS 2.0 software (Marshall et al., 1998) by the following parameters: number of alleles, observed heterozygosity $\left(H_{\mathrm{O}}\right)$, expected heterozygosity $\left(H_{\mathrm{E}}\right)$, and the polymorphism information content (PIC). Deviations from Hardy-Weinberg equilibrium were tested using the Genepop software (Raymond and Rousset, 1995).

\section{Cross-species amplification}

To evaluate cross-species amplification, all of these polymorphic markers were analyzed in 4 arctic foxes and 4 silver foxes. PCR conditions were the same as those for the Chinese raccoon dogs. Primer pairs that amplified fragments with a similar size to those observed in Chinese raccoon dog were considered to be successful cross-species amplifications.

\section{RESULTS AND DISCUSSION}

In the microsatellite-enriched library, 96 colonies were randomly selected, and 63 clones containing $(\mathrm{AC})_{\mathrm{n}}$ motifs by PCR screening were sequenced. The sequencing results revealed that 52 clones contained more than $5 \mathrm{CA}$ or TG repeats. The number of CA or TG repeats in these clones ranged from 5 to 24 . Of the 52 clones, 11 had compound repeat motifs, 28 had perfect motifs, and 13 had imperfect motifs. Forty-one primer pairs were designed for microsatellite sequences that contained at least 8 repeats and possessed sufficient flanking sequences that were suitable for primer design. Twenty-one loci produced specific products 
while other primers showed multi-banded patterns or non-specific amplification. Of the 21 loci, 17 loci exhibited polymorphisms in the 48 individuals that were tested. The primer sequences, motif information, number of alleles, PCR product size, and the GenBank accession number of the sequences of these 17 loci are shown in Table 1. The number of alleles per locus ranged from 2 to 8 . The $H_{\mathrm{E}}$ and $H_{\mathrm{O}}$ per locus ranged from 0.383 to 0.8378 with an average of 0.6415 and 0.3200 to 0.8696 with an average of 0.5994 , respectively. The PIC ranged from 0.3047 to 0.7947 with an average of 0.5852 . No deviations from Hardy-Weinberg equilibrium were observed in the population tested.

Table 1. Characteristics of the polymorphic microsatellite markers developed for Chinese raccoon dog.

\begin{tabular}{|c|c|c|c|c|c|c|c|c|}
\hline Locus & Primer sequences $\left(5^{\prime} \rightarrow 3^{\prime}\right)$ & Motifs & $N_{\mathrm{A}}$ & $\begin{array}{l}\text { Size range* } \\
\text { (bp) }\end{array}$ & $H_{\mathrm{O}}$ & $H_{\mathrm{E}}$ & PIC & $\begin{array}{c}\text { GenBank } \\
\text { No. }\end{array}$ \\
\hline NPPM 2 & $\begin{array}{l}\text { F: GGCATCGGTTCTAGTACCTTCT } \\
\text { R: CCTTTGCACCTCCAAGTGTTAG }\end{array}$ & $(\mathrm{AC})_{17}(\mathrm{ACC})_{5}$ & 5 & $215-227$ & 0.7083 & 0.7899 & 0.7383 & JN816363 \\
\hline NPPM 30 & $\begin{array}{l}\text { F: AGGACTATTTCACGCCTTGTTG } \\
\text { R: ATTCCCACCTCAGTGATTACAG }\end{array}$ & $(\mathrm{TG})_{16}$ & 6 & $276-286$ & 0.7917 & 0.8378 & 0.7947 & JN816364 \\
\hline NPPM244 & $\begin{array}{l}\text { F: GTCACTTAATAGGATGATTTCTTGG } \\
\text { R: CTAAAACCTGGATTGTCTAATTTGT }\end{array}$ & $(\mathrm{CT})_{8} \mathrm{~T}(\mathrm{TC})_{7}(\mathrm{TG})_{8}$ & 8 & $315-338$ & 0.6667 & 0.7172 & 0.6540 & JN816365 \\
\hline NPPM755 & $\begin{array}{l}\text { F: ATCAGCCTGTCTGCCATGTC } \\
\text { R: CTGGATTTCTCATGTCAACTGGA }\end{array}$ & $(\mathrm{CA})_{20} \mathrm{~N}_{12}(\mathrm{CA})_{11}$ & 3 & $221-269$ & 0.5000 & 0.5426 & 0.4683 & JN816366 \\
\hline NPPM981 & $\begin{array}{l}\text { F: GAACATCTTCCTTCTTCCACTG } \\
\text { R: TCCTAGAGACCTGGGATGAAGT }\end{array}$ & $(\mathrm{AC})_{20}$ & 5 & $318-328$ & 0.6250 & 0.6374 & 0.5842 & JN816367 \\
\hline NPPM10 & $\begin{array}{l}\text { F: GTGGACCATGTGACTCTTGA } \\
\text { R: TTTGTGTGATGCCACTACAGTAAG }\end{array}$ & $(\mathrm{TG})_{11}$ & 4 & 176-182 & 0.5417 & 0.5895 & 0.5333 & JN816368 \\
\hline NPPM902 & $\begin{array}{l}\text { F: TCATGGAAACAGAAGGCTTG } \\
\text { R: TGTCACCATTTCCTGTTGCTC }\end{array}$ & $\begin{array}{l}(\mathrm{TG})_{10} \mathrm{~N}_{12}(\mathrm{TG})_{5} \\
\mathrm{C}(\mathrm{GT})_{7} \mathrm{~A}(\mathrm{TG})_{5}\end{array}$ & 3 & 303-307 & 0.4167 & 0.4867 & 0.4275 & JN816369 \\
\hline NPPM930 & $\begin{array}{l}\text { F: TCTTTACCCTTCTGGAAAATGAG } \\
\text { R: GTGATTGAACACGCAAGGGAT }\end{array}$ & $(\mathrm{TC})_{18}(\mathrm{AC})_{18}^{3}$ & 6 & $247-262$ & 0.7500 & 0.7872 & 0.7379 & JN816370 \\
\hline NPPM5 & $\begin{array}{l}\text { F: GATCCCAGAAGTCAGACATTTAC } \\
\text { R: AGCTCTAGGGTGGAGGCTTCA }\end{array}$ & $(\mathrm{AC})_{15}$ & 2 & 200-204 & .3333 & 0.3830 & 0.3047 & JN816371 \\
\hline NPPM855 & $\begin{array}{l}\text { F: TGAGTTTTTGGTCCCCTCCA } \\
\text { R: CTCTGGTCCAGCAGTTGAAAC }\end{array}$ & $(\mathrm{AC})_{9} \mathrm{AT}(\mathrm{AC})_{9}$ & 5 & $226-238$ & .8696 & 0.8048 & 0.7534 & JN816372 \\
\hline NPPM609 & $\begin{array}{l}\text { F: TTTGGGGTCACTCAGATAGGAAG } \\
\text { R: TTTTCCAGAAGGGAGAACAGGT }\end{array}$ & $(\mathrm{GT})_{11}$ & 4 & 203-209 & 4583 & 0.4991 & 0.4515 & JN816373 \\
\hline NPPM769 & $\begin{array}{l}\text { F: TGGTAGCCACAGAAGCATTG } \\
\text { R: TTGGATTAAGTGTGTAGTCCTGAGC }\end{array}$ & $(\mathrm{GT})_{21}$ & 7 & $218-238$ & .6250 & 0.7323 & 0.6839 & JN816374 \\
\hline NPPM858 & $\begin{array}{l}\text { F: CAGTTTGCTACCTTTTGTGTAATCA } \\
\text { R: CTCACCCATTGTAGTCTCTGTCTTC }\end{array}$ & 15 & 6 & $187-204$ & 6667 & 0.7473 & 0.6895 & JN816375 \\
\hline NPPM965 & $\begin{array}{l}\text { F: AGAGCAAAGAAACAGGGCTATAG } \\
\text { R: GCTGATTTTGTGTTCTGCTCTGT }\end{array}$ & $(\mathrm{GT})_{10}$ & 3 & $237-245$ & 4583 & 0.5071 & 0.4427 & JN816376 \\
\hline NPPM840 & $\begin{array}{l}\text { F: AGCTGTGGTAGAGTTAAGGCTGTGT } \\
\text { R: GCTCTCTGGTCACTATTATCCTGT }\end{array}$ & $(\mathrm{GT})_{18}(\mathrm{GA})_{28}$ & 3 & 291-295 & .3200 & 0.3886 & 0.3326 & JN816377 \\
\hline NPPM905 & $\begin{array}{l}\text { F: TCCAGAGTCACAACTTCAGAAAC } \\
\text { R: GCTAGATTGCTGCCCTTTACTC }\end{array}$ & $(\mathrm{TG})_{20}$ & 6 & $201-221$ & 0.7083 & 0.7411 & 0.6891 & JN816378 \\
\hline NPPM941 & $\begin{array}{l}\text { F: CCAGCCAGGAGACTAAAGCCA } \\
\text { R: TGAAAGGGAAAGTCAGATGGAG }\end{array}$ & $(\mathrm{TG})_{20}$ & 5 & $191-223$ & 0.7500 & 0.7145 & 0.6636 & JN816379 \\
\hline
\end{tabular}

Among the 17 polymorphic microsatellite loci, 9 loci (NPPM2, NPPM30, NPPM244, NPPM902, NPPM855, NPPM609, NPPM965, NPPM905, and NPPM941) and 11 loci (the 9 mentioned above, NPPM930, and NPPM840) were successfully amplified in arctic and silver fox, respectively. The results indicated that the microsatellite loci have a varying degree of transferability and that they have possible usefulness as genetic markers in the 2 species, whose microsatellite markers were limited.

In summary, the 17 polymorphic microsatellite loci developed in this study will pro- 
vide useful tools to investigate the population genetic structure and diversity in the farmed Chinese raccoon dogs and other Canidae species.

\section{ACKNOWLEDGMENTS}

Research supported by projects of the National Natural Science Foundation of China (\#31072018).

\section{REFERENCES}

Hayashizono N, Ago K, Hayashi T, Ago M, et al. (2010). Amplification of microsatellites of Japanese raccoon dogs (Nyctereutes procyonoides viverrinus) with primers for the dog ZUBECA4 locus. Med. J. Kagoshima Univ. 61: 41-46.

Lunt DH, Hutchinson WF and Carvalho GR (1999). An efficient method for PCR-based isolation of microsatellite arrays (PIMA). Mol. Ecol. 8: 891-893.

$\mathrm{Ma} \mathrm{H}$ and Chen S (2011). Development of polymorphic microsatellite markers in barfin flounder (Verasper moseri) and spotted halibut (Verasper variegatus) by the cross-species amplification. Mol. Biol. Rep. 38: 4545-4551.

Marshall TC, Slate J, Kruuk LE and Pemberton JM (1998). Statistical confidence for likelihood-based paternity inference in natural populations. Mol. Ecol. 7: 639-655.

Novelli VM, Cristofani M, Souza AA and Machado MA (2006). Development and characterization of polymorphic microsatellite markers for the sweet orange (Citrus sinensis L. Osbeck). Genet. Mol. Biol. 29: 90-96.

Raymond $\mathrm{M}$ and Rousset F (1995). GENEPOP (version 1.2): Population genetics software for exact tests and ecumenicism. J. Hered. 86: 248-249.

Schuelke M (2000). An economic method for the fluorescent labeling of PCR fragments. Nat. Biotechnol. 18: 233-234.

Sha ZX, Xing SC, Shao CW, Tian YS, et al. (2009). Isolation and characterization of 12 polymorphic microsatellite markers from ladyfish (Elops saurus Linnaeus). Conserv. Genet. 10: 1799-1801.

Slaska B, Zieba G, Rozempolska-Rucinska I, Jezewska-Witkowska G, et al. (2010). Evaluation of genetic biodiversity in farm-bred and wild raccoon dogs in Poland. Folia Biol. 58: 195-199.

Zhao X and Kochert G (1993). Phylogenetic distribution and genetic mapping of a (GGC)n microsatellite from rice (Oryza sativa L.). Plant Mol. Biol. 21: 607-614. 